Journal of Korean Powder Metallurgy Institute

Vol. 16, No. 6, 2009

DOI: $10.4150 /$ KPMI.2009.16.6.424

\title{
$\mathrm{Fe}$ 계 나노결정립 분말 시트에 첨가된 $\mathrm{CNT}$ 의 볼밀 공정에 따른 전자파 흡수 특성 변화 \\ 김선이 · 김미래 · 손근용 · 박원욱* \\ 인제대학교 나노시스템 공학과
}

\section{The Characteristic Changes of Electromagnetic Wave Absorption in Fe-based Nanocrystalline P/M Sheets Mixed with Ball-Milled Carbon Nanotubes}

\author{
Sun-I Kim, Mi-Rae Kim, Keun Yong Sohn and Won-Wook Park* \\ Department of Nano System Engineering, Inje University, 607 Obang-dong \\ Gimhae, Gyungnam, 621-749, Republic of Korea \\ (Received October 16, 2009; Revised November 6, 2009; Accepted November 23, 2009)
}

\begin{abstract}
Electromagnetic wave energies are consumed in the form of thermal energy, which is mainly caused by magnetic loss, dielectric loss and conductive loss. In this study, CNT was added to the nanocrystalline soft magnetic materials inducing a high magnetic loss, in order to improve the dielectric loss of the EM wave absorption sheet. Generally, the aspect ratio and the dispersion state of CNT can be changed by the pre-ball milling process, which affects the absorbing properties. After the various ball-milling processes, $1 \mathrm{wt} \%$ of CNTs were mixed with the nanocrystalline $\mathrm{Fe}_{73} \mathrm{Si}_{16} \mathrm{~B}_{7} \mathrm{Nb}_{3} \mathrm{Cu}_{1}$ base powder, and then further processed to make EM absorption sheets. As a result, the addition of CNT to Fe-based nanocrystalline materials improved the absorption properties. However, the increase of ball-milling time for more than $1 \mathrm{~h}$ was not desirable for the powder mixture, because the ballmilling caused the shortening of CNT length and the agglomeration of the CNT flakes.
\end{abstract}

Keywords : Electromagnetic wave absorber, $\mathrm{FeSiBNbCu}, \mathrm{CNT}$, Ball milling, Complex permittivity

\section{1. 서 론}

정보화 사회에서 전자파는 중요한 자원으로 활용 되고 있으며, 산업기술의 발달과 함께 전자파의 사용 량이 급증하고 있다. 전자파는 정보 전달 및 음식을 시키는 등 우리 주변에서 다양하게 이용되고 있다. 전자파는 우수한 장점을 많이 가지고 있지만, 우리의 의도와 관계없이 전자기기에서 발생되는 전자파는 많 은 문제를 일으킨다. 전자파는 전자기기의 정상 작동 을 방해하여 기기의 오작동을 유발시킬 뿐만 아니라 복사되는 전자파는 인체내의 호르몬을 자극시켜 몸 의 면역세포의 기능을 약화시키고 또한 암의 발생률 을 증가시킨다. 이러한 전자파의 피해를 억제하기 위 한 대책으로 전자파 흡수체의 연구가 대두되고 있다.
전자파의 흡수는 입사된 전자파에너지가 전자파 흡 수체의 손실유전체나 손실자성체 재료의 전기적 특 성에 따라 에너지가 감쇠된다. 전자파에너지의 손실 은 자성손실, 유전손실, 도전손실로 분류되는데 고주 파에서는 유전손실과 도전손실을 나누어 설명할 수 없 기 때문에 자성손실과 유전손실에 의하여 에너지를 흡 수한다고 볼 수 있다[1]. 따라서, 자성손실과 유전손실 의 주요 요소인 복소 투자율과 유전율의 값에 따라 전자파 흡수체의 흡수능이 크게 변화하게 된다[2].

현재까지 유전 손실을 이용한 유전성 흡수체와 자 성 손실을 이용한 자성 흡수체에 관한 많은 연구들 이 활발히 진행되고 있지만 이러한 흡수체는 몇몇 문 제점이 있다. 자성 손실을 이용한 흡수체의 경우는 시트의 무게가 무거워지며 또한 고주파 대역에서 특

*Corresponding Author : [Tel : +82-55-320-3872; E-mail : wwpark@inje.ac.kr] 
성이 떨어진다는 단점이 있다. 또한, 유전손실을 이 용한 흡수체의 경우에는 정합 조건을 만족시키기 위 해서는 흡수체 시트가 두꺼워지고, 제한된 주파수 대 역에서만 우수한 흡수 특성을 나타낸다는 단점이 있 다. 따라서 각각의 유전성 흡수체와 자성 흡수체의 문제점을 보완하고자 본 실험에서는 유전성 손실재 료와 자성 손실재료가 함께 적용된 흡수체를 연구하 였다.

자성손실 재료로는 나노결정립 연자성 재료를 사 용하였다. 현재까지 연구되고 있는 자성 손실재료는 페라이트 (Ferrite)와 센더스트 (Sendust)가 주를 이루 고 있으나[3-5] 시트의 두께가 두껍다는 단점이 있다 [6]. 이에 반하여 최근 인덕션 코어로 많이 사용되고 있는 나노결정립 연자성 재료는 미소결정립으로 인 하여 높은 투자율과 포화자속밀도[7, 8]를 나타냄으로 써 얇은 두께로도 우수한 흡수능을 나타내는 흡수체 를 제조할 수 있다는 장점이 있다[9].

유전손실 재료로는 대표적 탄소 나노소재인 카본 블랙, 숯 분말과 카본나노튜브를 선택하여 Fe계 연자 성 분말에 첨가한 후 그 영향을 분석하였다. 그러나 첨가원소 중에서 가장 우수한 흡수능을 나타내는 $\mathrm{CNT}$ 의 경우, 자체의 부피가 커서 첨가 시에 제조공 정상 어려움이 발생하였으며 쉽게 응집이 된다는 단 점이 있었다. 따라서, 본 연구에서는 이러한 $\mathrm{CNT}$ 의 첨가과정에서 발생하는 어려움을 해결하고자 첨가 이 전에 CNT를 볼밀링기[10]를 이용하여 CNT의 부피 를 감소시켜 줌과 아울러 길이/직경 비의 변화를 주 어 $\mathrm{Fe}$ 계 분말에 첨가함으로써 시트제조 공정의 향상 과 흡수체 시트의 특성을 향상시키고자 하였다.

\section{2. 실험방법}

급속냉각응고법을 이용하여 $\mathrm{Fe}_{73} \mathrm{Si}_{16} \mathrm{~B}_{7} \mathrm{Nb}_{3} \mathrm{Cu}_{1}$ 의 비 정질 합금을 리본형태로 제조하였다. 제조된 비정질 리본은 제트밀(Jet mill)과 어트리션밀(Attrition mill) 을 사용하여 편상화 형태의 분말을 제조한 후, 편상 화된 $\mathrm{Fe}$ 분말들 중 $54 \mu \mathrm{m}$ 이하 크기의 분말만 분급 하여 $540^{\circ} \mathrm{C}$ 에서 1 시간 동안 열처리 과정을 거쳐 고 투자율의 나노결정립 분말을 얻었다. 유전손실의 값 을 향상시키기 위해 첨가된 도전체인 카본블랙, 숯 분 말, $\mathrm{CNT}$ 은 전체 분말의 $1 \mathrm{wt} \%$ 를 첨가한 후 지름 $20 \mathrm{~mm}$ 인 스틸볼을 사용하여 30 분간 혼합과정을 거쳤
다. 혼합된 분말에 폴리머인 바인더와 경화제를 전체 부피의 $40 \%$ 정도 첨가하여 분말을 슬러리 상태로 만든 후 캐스팅기를 사용하여 두께 $1 \mathrm{~mm}$ 인 시트형 태로 제조하였다. 제조된 시트는 $100^{\circ} \mathrm{C}$ 에서 2시간, 상온에서 24시간 동안 건조과정을 거쳐 최종적으로 $70^{\circ} \mathrm{C}$ 로 예열된 롤링기를 사용하여 두께 $0.5 \mathrm{~mm}$ 인 전자파 흡수체 시트로 제조하였다.

$\mathrm{CNT}$ 를 $\mathrm{Fe}$ 계 분말에 첨가하기 이전에 $\mathrm{CNT}$ 의 길 이/직경 비를 변화시키기 위하여 볼밀링 하였는데, 이 경우 (1) 볼밀링의 시간과 (2)사용하는 볼의 종류 및 직경을 변화시켰다. 지름이 $20 \mathrm{~mm}$ 인 스틸(Steel)볼을 사용하는 경우, 볼밀링 시간을 $1,2,5,10$ 시간으로 변화시켰으며, 사용하는 볼의 종류와 직경 변화에 따 른 $\mathrm{CNT}$ 의 변화를 관찰하기 위한 실험에서는 볼밀링 시간을 1시간으로 고정한 후, 지름 $20 \mathrm{~mm}, 6.3$ $\mathrm{mm}, 4.7 \mathrm{~mm}$ 의 스틸볼과 지름 $10 \mathrm{~mm}$ 의 지르코늄 의 볼을 사용하였다. 볼밀의 각 조건에 따라 변화된 $\mathrm{CNT}$ 를 자성분말에 전체 분말의 $1 \mathrm{wt} \%$ 첨가한 후 $20 \mathrm{~mm}$ 인 스틸볼을 사용하여 30 분간 혼합과정을 거 친 후 바인더 폴리머 소재를 $40 \%$ 혼합하여 위의 실 험과 동일과정을 거쳐 최종적으로 두께 $0.5 \mathrm{~mm}$ 인 전자파 흡수체를 제조하였다.

전자파 흡수능에 영향을 미치는 시트의 유전율, 투 자율과 흡수능은 네트워크 분석기(network analyzer), (Agilent Co. N5230A)의 두 개의 포트(port) 끝 단 의 커넥터와 $7 \mathrm{~mm}$ 동축관 및 마이크로 스트립 (Microstrip)을 연결하여 측정하였다. 시험편은 외경 7 $\mathrm{mm}$, 내경 $3 \mathrm{~mm}$ 의 환상(toroidal)형태로 가공하거나 가로 세로 각각 $5 \mathrm{~cm}$ 인 정사각형 형태로 가공하여 제조하였다. 복소 유전율은 네트워크 분석기에서 10 $\mathrm{MHz} 10 \mathrm{GHz}$ 의 주파수 범위에서 측정된 산란 요소 (Scattering parameter)로부터 계산되어 나온 값으로부 터 얻었다[2]. 볼밀링 조건 변화에 따른 CNT의 길이 변화 및 $\mathrm{Fe}$ 분말에 분산된 정도는 $\mathrm{FE}-\mathrm{SEM}$ 을 이용 하여 살펴보았다.

\section{3. 실험 결과 및 고찰}

$\mathrm{Fe}$ 계 분말에 탄소나노소재인 도전체를 $1 \mathrm{wt} \%$ 첨가 한 후 제조한 전자파 흡수시트의 주파수 대역에 따 른 흡수능 변화를 측정한 결과를 그림 1 에 나타내었 다. 마이크로 사이즈의 카본블랙, 나노 사이즈의 카 


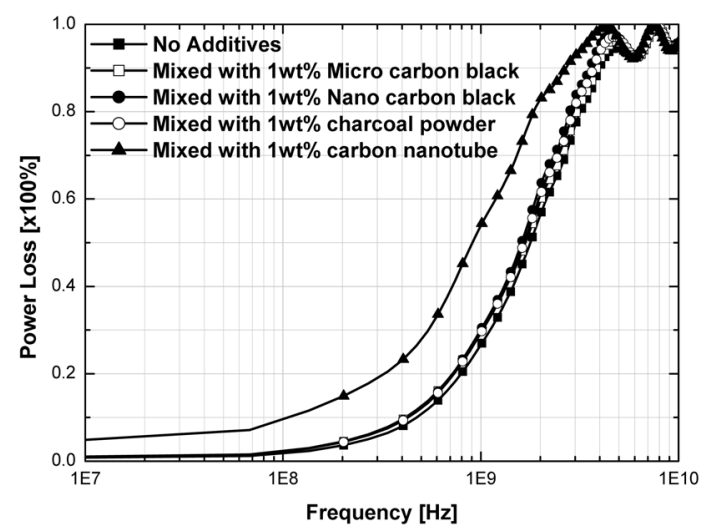

Fig. 1. Power loss curve for the nanocrystalline soft magnetic $\mathrm{P} / \mathrm{M}$ sheets, mixed with $1 \mathrm{wt} \%$ of various conductive powder in the $10 \mathrm{MHz}-10 \mathrm{GHz}$ frequency range.

본블랙과 숮분말 $1 \mathrm{wt} \%$ 를 자성분말에 첨가한 전자 파 흡수시트의 흡수율은 $\mathrm{Fe}$ 계 나노결정립 연자성 분 말만 사용하여 제조한 자성 흡수체의 흡수능과 1 $\mathrm{GHz}$ 대역에서 비교하여 보았을 때, 흡수능에 큰 변 화를 나타내지 않았다. 그에 반하여, CNT를 첨가한 전자파 흡수체의 경우, 흡수능이 자성 흡수체의 흡수 능인 $30 \%$ 에서 $55 \%$ 로 약 2 배 가량 급격하게 커지는 것을 볼 수 있다. 이 결과의 원인으로 CNT고유의 형태 때문으로써 길이/직경 비 값이 커서 적은 양을 첨가하여도 전도성 Path가 형성되어 높은 도전율을 나타냄으로써 유전손실이 크게 증가하여 흡수능이 급 격히 증가한 것으로 판단된다[11-12].

그림 2는 $\mathrm{CNT}$ 를 볼밀링 함에 따른 $\mathrm{CNT}$ 의 부피 변화를 관찰한 사진이다. CNT를 1시간 동안 볼밀링 하였을 때 볼밀링 하기 전의 전체 부피의 약 $50 \%$ 가 량 감소한 것을 관찰할 수 있었고, 볼밀링 시간이 증 가됨에 따라 CNT의 부피가 감소하는 것을 알 수

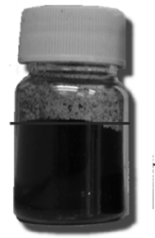

No ball mill

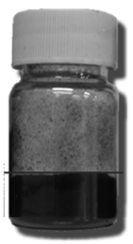

1hr

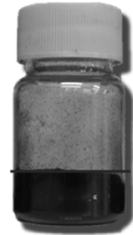

2hr

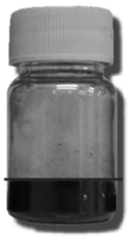

$5 \mathrm{hr}$

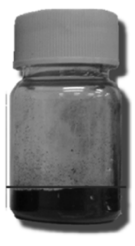

$10 \mathrm{hr}$
Fig. 2. The photographs showing the volume state changes of CNT (10 20 nm in diameter) according to the pre-ball milling time up to $10 \mathrm{~h}$.
있었다. 이의 결과는 동일한 무게비로 $\mathrm{CNT}$ 를 첨가 하더라도 첨가되는 $\mathrm{CNT}$ 의 부피가 감소함에 따라 분 말 시트에 첨가되는 폴리머의 양이 줄어들어 제조과 정이 간편해 지고, 제조공정의 효율을 향상시킬 수 있었다.

그림 3은 CNT를 볼밀링 함에 따라 CNT 길이의 변화를 관찰하기 위하여 $\mathrm{Fe}$ 계 자성분말에 $\mathrm{CNT}$ 를 첨 가한 후 혼합한 분말의 SEM사진이다. CNT의 볼밀 링 시간이 증가함에 따라 점차적으로 $\mathrm{CNT}$ 의 길이가 전반적으로 짧아지는 것을 관찰 할 수 있었고, 이에 따라 길이/직경 비 값이 감소하는 것을 추측할 수 있 다. 또한 그림 3 의 (e), (f)에서 CNT의 응집현상이 관찰되었다. 이는 장시간 $\mathrm{CNT}$ 를 볼밀링 할 경우, 사 용된 볼과 CNT간에 정전기 현상이 발생하는 것으로 알려져 있는데[13], 이 결과 또한 위와 같은 현상에 의해서 CNT가 응집된 것으로 판단된다.

그림 4는 CNT볼밀 공정 시간을 변화시켜 길이/직 경 비가 변화된 $\mathrm{CNT}$ 를 첨가하여 제조한 전자파 흡 수시트의 복소 유전율을 나타낸 것이다. CNT를 첨 가함에 따라 모든 시트의 복소 유전율은 크게 증가 하였다. 이의 원인으로는 높은 전도도를 가지는 CNT 가 절연체인 바인더에 코팅되어 계면분극 현상[14]을 발생시켜 높은 유전율을 나타낸 것이다. 그렇지만 볼 밀 공정 시간이 증가함에 따라 전자파 흡수체의 유 전율이 감소하는 것을 알 수 있었다. 이의 원인은 볼 밀 시간에 증가함에 따라 길이/직경 비 값이 줄어들 어 퍼콜레이션 (Percolation)을 발생시키기가 어려워 져서 전반적으로 동일 양을 첨가하더라도 $\mathrm{CNT}$ 첨가 에 따른 도전율이 감소하여 결과적으로 유전율이 감 소한 것으로 판단된다. 또한, SEM 사진에서도 관찰 할 수 있듯이 볼밀링 5 시간 이후에는 CNT간에 응집 현상 발생하여 CNT가 자성 분말 내에 균일하게 분 산되기 어려워 유전율이 떨어진 것으로 사료된다.

그림 5는 전자파 흡수시트의 복소 투자율을 나타 낸 것이다. CNT를 첨가함에 따라 실수 및 허수 투 자율의 약간의 감소만 나타났고, $\mathrm{CNT}$ 의 볼밀 공정 시간에 아무런 변화를 나타내지 않았다. 이러한 결과 로부터, 복소투자율의 경우, 첨가되는 CNT의 특성에 는 크게 영향을 받지 않고 첨가되는 양에만 크게 영 향을 받는 것으로 사료된다.

그림 6은 CNT 볼밀 공정 시간의 변화에 따른 전 자파 흡수시트의 흡수능을 나타낸 것이다. CNT를 첨 


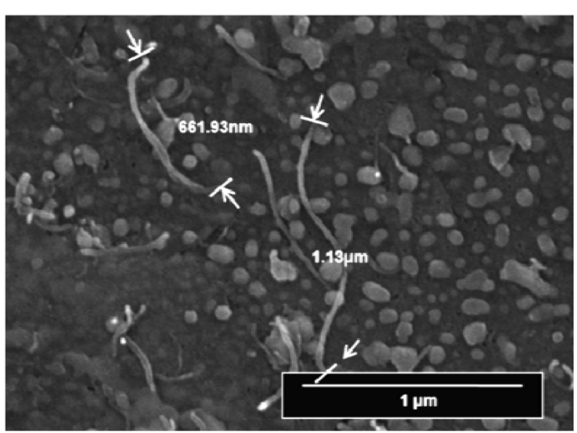

(a)

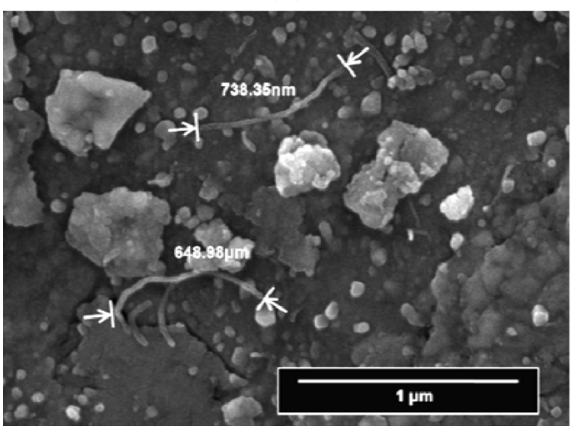

(c)

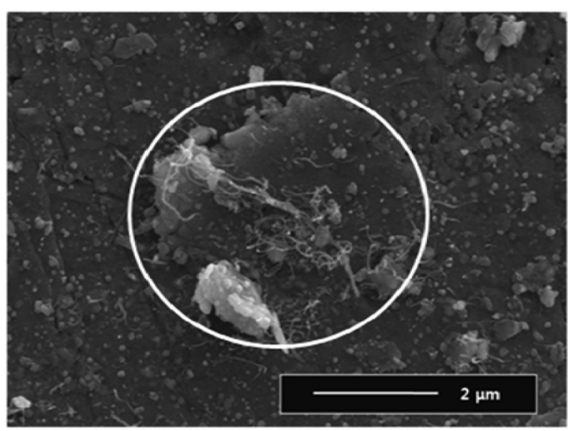

(e)

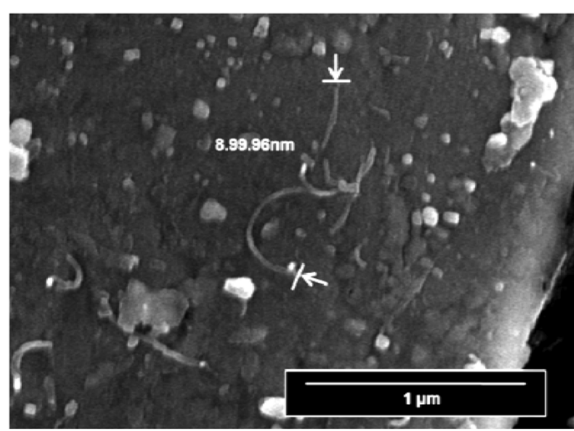

(b)

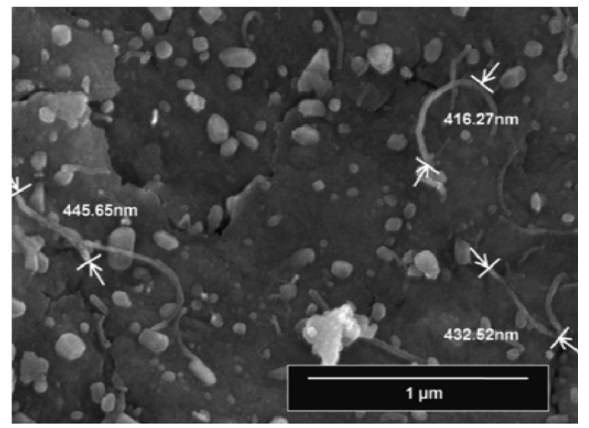

(d)

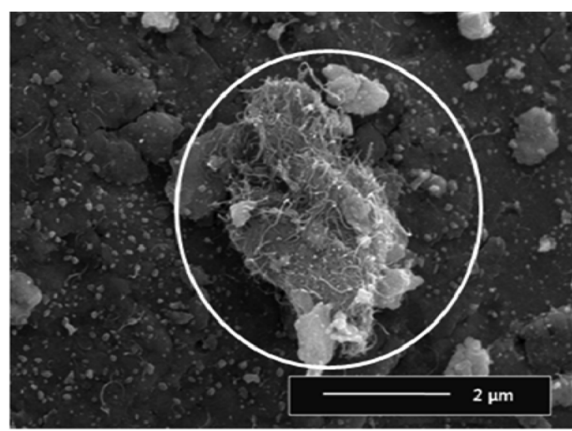

(f)

Fig. 3. The SEM images showing the dispersion state changes of CNT (10 $20 \mathrm{~nm}$ in diameter) according to the Pre-ball milling time of (a) $1 \mathrm{~h}$, (b) $2 \mathrm{~h}$, (c) $5 \mathrm{~h}$, (d) $10 \mathrm{~h}$, (e) $5 \mathrm{~h}$, and (f) $10 \mathrm{~h}$ in the powder mixtures.

가하지 않는 경우에는 흡수능이 $30 \%$ 정도였으나 $\mathrm{CNT}$ 를 첨가함에 따라 흡수능이 크게 향상된 것을 관찰할 수 있었다. 이러한 결과는 투자율에는 크게 변화가 없으나 유전율이 크게 증가하여 유전손실이 증가하는 현상에 기인한 것으로 판단된다. $\mathrm{CNT}$ 를 1 시간 볼밀링한 경우에는 크게 흡수능이 떨어지지 않 았으나 볼밀링 시간이 점차적으로 증가함에 따라 크 게 흡수능이 떨어지는 것을 관찰할 수 있었다. 이는 볼밀 시간이 증가함에 따라 전자파 흡수 시트의 유
전율이 비례적으로 감소하고, 또한 CNT를 볼밀 공 정시에 고 에너지의 볼이 $\mathrm{CNT}$ 를 자르는 과정에서 $\mathrm{CNT}$ 의 표면 결함을 유발될 뿐만 아니라 CNT가 비 정질구조의 탄소가 되는 것으로 알려져 있는데 [15], 그러한 결과를 통하여 전자파 흡수 특성이 떨어진 것 으로 사료된다.

결과적으로 $\mathrm{CNT}$ 를 볼밀링 할 때 볼밀 공정 시간 을 증가시킴에 따라 $\mathrm{CNT}$ 의 부피는 줄어들어 전자파 흡수체 제조과정의 효율을 향상되나 시트의 흡수능은 


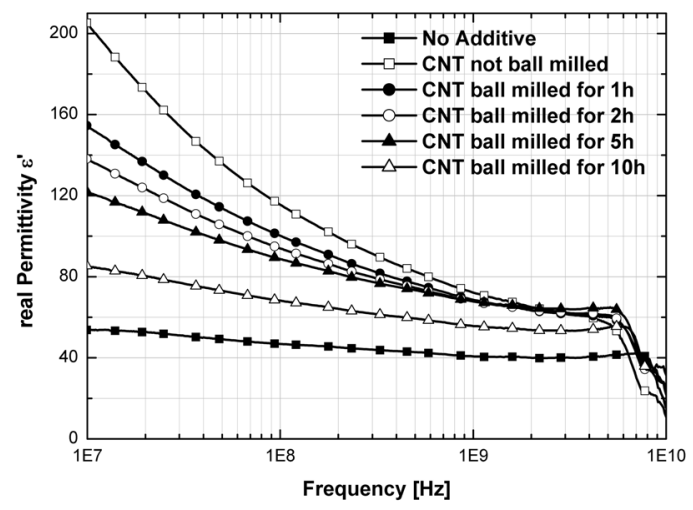

(a)

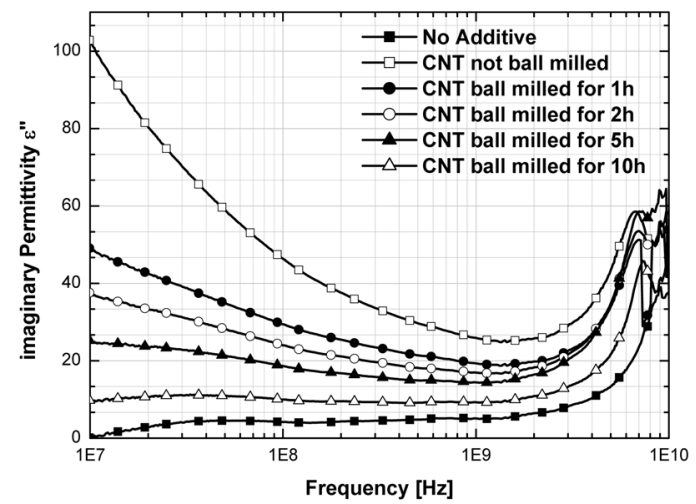

(b)

Fig. 4. (a) the real part of complex permittivity $\left(\varepsilon_{r}{ }^{\prime}\right)$, (b) the imaginary part of complex permittivity $\left(\varepsilon_{r}{ }^{\prime \prime}\right)$ curves plotted against frequency for the $\mathrm{Fe}$-based $\mathrm{EM}$ wave absorption sheets, mixed with $1 \mathrm{wt} \% \mathrm{CNT}$ ball milled for various time in the $10 \mathrm{MHz}-10 \mathrm{GHz}$ range.

급격히 떨어지는 경향을 나타내었다. 따라서, CNT를 적정시간 볼밀링 하였을 경우는 첨가되는 $\mathrm{CNT}$ 의 부 피 감소로 인하여 제조공정의 효율을 향상시킬 뿐만 아니라 CNT를 첨가함에 따른 전자파 흡수시트의 흡 수능에도 크게 영향을 받지 않으므로 전자파 흡수체 제조공정에 도움이 되는 것으로 판단된다.

그림 7은 볼밀링 시간을 1시간으로 고정하고, 사용 하는 볼의 종류를 달리하여 $\mathrm{CNT}$ 를 가공하여 제조한 후 측정한 전자파 흡수체의 흡수능의 결과이다. 볼의 종류나 크기에 따라 흡수능의 값은 크게 변화되지 않 은 것을 알 수 있었다. 이러한 결과로부터 $\mathrm{CNT}$ 를 1 시간 동안 볼밀링 할 때는 사용한 볼의 영향을 크게 받지 않는 것으로 판단되었다.

$\mathrm{CNT}$ 볼밀 공정에서 볼의 크기와 볼의 종류의 영향

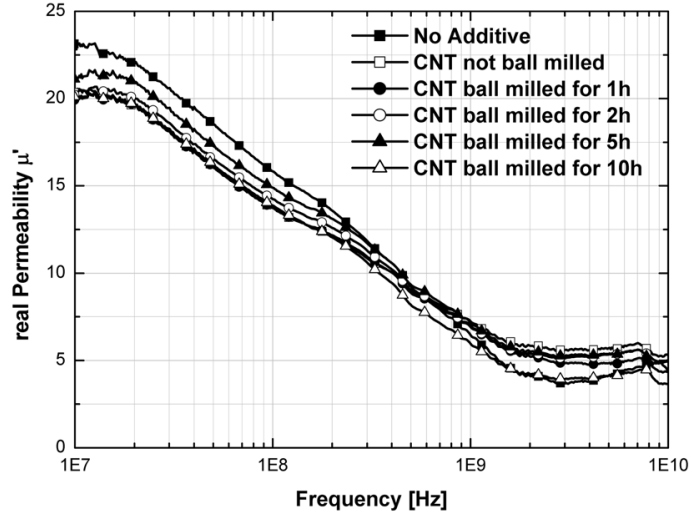

(a)

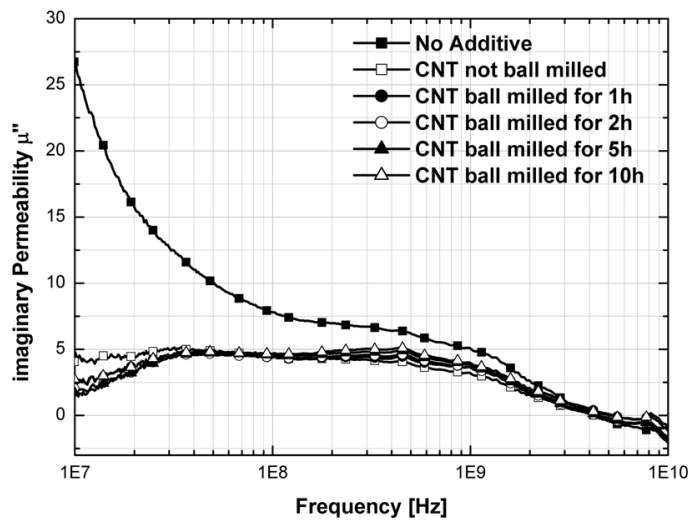

(b)

Fig. 5. (a) the real part of complex permeability $\left(\mu_{r}{ }^{\prime}\right)$, (b) the imaginary part of complex permeability $\left(\mu_{r}{ }^{\prime \prime}\right)$ curves plotted against frequency for the Fe-based EM wave absorption sheets, mixed with $1 \mathrm{wt} \% \mathrm{CNT}$ ball milled for various time in the $10 \mathrm{MHz}-10 \mathrm{GHz}$ range.

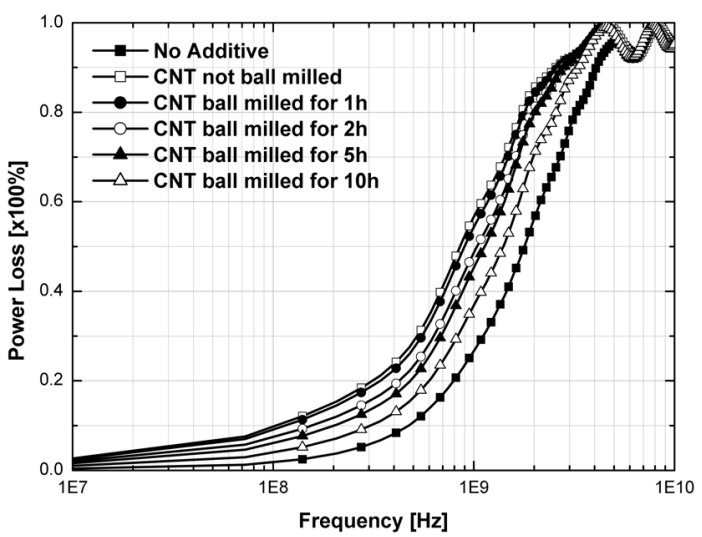

Fig. 6. Power loss curve for the Fe-based nanocrystalline soft magnetic powder sheets, mixed with $1 \mathrm{wt} \%$ CNT ball milled for various time in the $10 \mathrm{MHz}-10 \mathrm{GHz}$ range. 


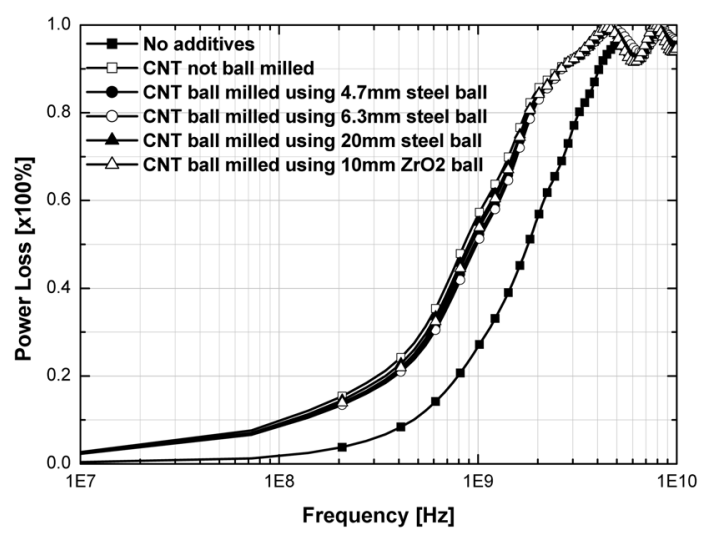

Fig. 7. Power loss curve for the Fe-based nanocrystalline soft magnetic powder sheets, mixed with $1 \mathrm{wt} \%$ CNT ball milled for $1 \mathrm{~h}$ using various balls in the $10 \mathrm{MHz}-10 \mathrm{GHz}$ range.

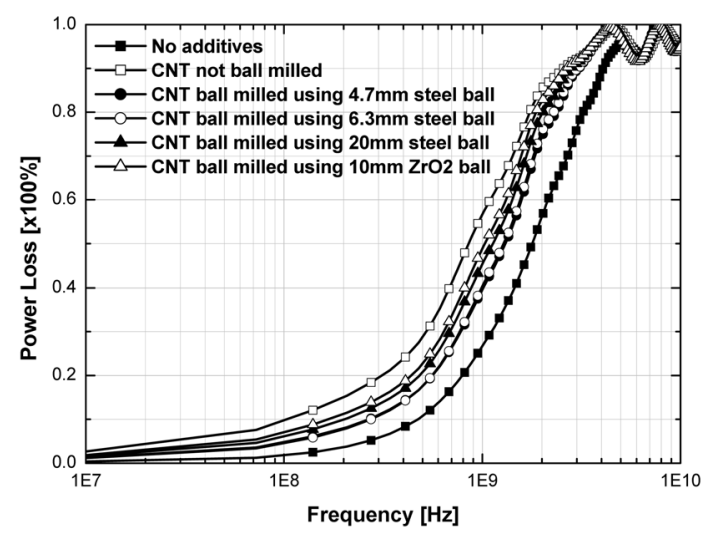

Fig. 8. Power loss curve for the Fe-based nanocrystalline soft magnetic powder sheets, mixed with $1 \mathrm{wt} \%$ CNT ball milled for $5 \mathrm{~h}$ using various balls in the $10 \mathrm{MHz}-10 \mathrm{GHz}$ range.

을 좀더 관찰하기 위하여 볼밀링 시간은 5 시간으로 고정한 채, 사용하는 볼의 종류와 크기를 다르게 하 여 CNT에 변화를 주었다. 변화된 CNT를 자성 분 말에 첨가하여 전자파 흡수체의 흡수능의 변화를 측 정한 결과를 그림 8 에 나타내었다. 장시간의 볼밀링 시간으로 인하여 전체적으로 흡수능이 떨어진 것을 관 찰할 수 있었다. 그러나 지르코늄볼을 사용하여 CNT 를 볼밀링 한 경우가 스틸볼을 사용한 경우보다 흡수 능이 높게 나타난 것을 알 수 있었다. 이러한 결과로 부터 지르코늄 볼이 CNT의 분산에는 좀더 효과적이 라는 결론을 얻을 수 있었고, 볼의 직경에 따라 흡수 능은 크게 차이가 없었으므로 $\mathrm{CNT}$ 의 분산에 볼의 크
기는 크게 영향을 주지 않은 것으로 분석되었다.

\section{4. 결 론}

$\mathrm{Fe}_{73} \mathrm{Si}_{16} \mathrm{~B}_{7} \mathrm{Nb}_{3} \mathrm{Cu}_{1}$ 의 나노결정립 연자성 분말에 볼 밀링과정을 거친 $\mathrm{CNT}$ 를 $1 \mathrm{wt} \%$ 첨가하여 성형한 전자파 흡수체의 특성변화에 관한 연구결과는 다음 과 같다.

$\mathrm{CNT}$ 를 $1 \mathrm{wt} \%$ 첨가함에 따라 전자파 흡수체 시 트의 흡수능이 $1 \mathrm{GHz}$ 대역에서 $30 \%$ 에서 $55 \%$ 로 두 배 가량 증가하였다.

$\mathrm{Fe}$ 계 나노결정립 연자성 분말에 첨가하기 이전에 $\mathrm{CNT}$ 를 볼밀링 할 경우, $\mathrm{CNT}$ 의 부피가 감소하여 제조공정이 크게 향상되며, 우수한 흡수능을 유지하 기 위해서는 $\mathrm{CNT}$ 를 1 시간 정도 볼밀링하여 첨가하 는 것이 가장 적합한 것으로 분석되었다.

$\mathrm{Fe}$ 계 나노결정립 연자성 분말에 첨가하기 이전에 $\mathrm{CNT}$ 를 1 시간 동안 볼밀링 할 경우, 사용되는 볼의 크기나 종류는 흡수능에 거의 영향을 주지 않았다. 이에 비해, $\mathrm{CNT}$ 를 비교적 장시간인 5시간 볼밀링할 경우에는, 강구보다 지르코니아 볼이 $\mathrm{CNT}$ 를 더욱 잘 분산시켜 전자파 흡수시트의 특성이 더 우수하게 나 타났다.

\section{참고문헌}

[1] J. R. Liu, M. Itoh, T. Horikawa, M. Itakura, N. Kuwano and K. Machida: J. Appl. Phys., 37 (2004) 2737.

[2] S. S. Kim, S. B. Jo, K. I. Gueon, K. K. Choi, J. M. Kim and K. S. Churn: IEEE Tans. Magn., 27 (1991) 5462.

[3] J. R. Liu, M. Itoh, K. Machida: Appl. Phys. Lett., 88 (2006) 062503

[4] J. H. Choi, D. I. Kim, J. M. Song and J. H. Jung: Journal of The Korean Electromagnetic Engineering Society, 16 (2005) 842.

[5] S. Yoshida, M. Sato, E. Sugawara and Y. Shimada: J. Appl. Phys., 85 (1999) 4636.

[6] T. Nakamura: J. Appl. Phys., 88 (2000) 348.

[7] Y. Yoshizawa and K. Yamauchi: IEEE Trans. Magn., 25 (1989) 3324.

[8] G. Herzer: IEEE Trans. Magn., 25 (1989) 3327.

[9] B. Hornbostel, U. Leute, P. Potschke, J. Kotz, D. Kornfeld, P. W. Chiu and S. Roth: Physica E, 40 (2008) 2425.

[10] N. Darsono, D. H. Yoon and J. Kim: Appl. Surf. Sci., 
254 (2008) 3412.

[11] J. I. Lee and H. T. Jung: Korean CHem. Eng.Res., 46 (2008) 7.

[12] D. D. L. Chung: Carbon, 39 (2001) 279.

[13] A. Esawi and K. Morsi: Composites: part A, 38 (2007) 646.
[14] S. I. Kim, M. R. Kim, K. Y. Sohn and W. W. Park: Journal of Korean Powder Metallurgy Institute, 16 (2009) 291.

[15] Z. Tao, H. Geng, K. Yu, Z. Yang and Y. Wang: Mater. Lett., 58 (2004) 3410. 